\title{
Project Library Ripoff: A Study of Periodical Mutilation in a University Library
}

A questionnaire study assessed 168 students on their knowledge and opinion about periodical mutilation in the Kent State University library. Three mutilators were also interviewed in detail. Fourteen students ( 8.3 percent) admitted to mutilation of journals. Statistical tests revealed few differences between mutilators and non-mutilators, although mutilators had generally less favorable attitudes toward the library. The data suggested certain preventive measures; the most important were a publicity campaign to educate students about the costs of mutilation, and specific penalty warning signs strategically located in the library.

M OST ACADEMIC LIBRARIES, however much they choose to ignore the problem, suffer from a debilitating disease. The quiet but insidious mutilation of their periodical collections not only drains badly needed financial resources but also frustrates and frequently infuriates their patrons. This paper reports on a questionnaire study which was conducted to learn about the dimensions of the problem, particularly about those students who engage in the act of mutilation.

The goals of the study were: (1) to determine the proportion of students in a sample who admit to periodical mutilation, (2) to examine the characteristics and attitudes of students who mutilate versus those who do not, (3)

Clyde Hendrick is associate professor of psychology and Mariorie E. Murfin is reference librarian and instructor in library administration at Kent State University, Kent, Ohio. to examine and analyze the actual circumstances of and reasons for acts of mutilation, and (4) to determine methods of prevention as suggested by students which would be most effective in reducing mutilation.

The need for such data is abundant, both from the standpoint of the patron and the library. In the present study 76 percent of Kent State students and in another unpublished study 73 percent of Bowling Green students reported having been inconvenienced at least once by mutilated articles. ${ }^{1}$ A study by R. G. Martin reported that 80 percent of the libraries surveyed considered that they had a serious mutilation problem. ${ }^{2}$ Various other aspects of the mutilation problem have been discussed in the literature. $^{3}$

The extent of mutilation is a budgetary consideration which, although small in relation to total library budget, is nonetheless significant. In these days of tight budgets libraries may be tempted 
to reduce replacement costs, or not to replace at all. However, to anticipate our data, such reduction may well cause a "chain reaction," leading to even higher mutilation rates.

Thus the magnitude of the problem is such that any insights leading to a reduced rate of mutilation would lead to substantial monetary savings, not to mention reduced frustration and anger on the part of library staff and patrons. In this context the present exploratory study seemed well worthwhile as a first attempt to systematize reasons and possible preventives for periodical mutilation.

\section{METHOD}

The study was conducted during the fall quarter of 1973. Students from classes in introductory psychology and social psychology at Kent State University served as subjects. The project was explained to subjects and the questionnaire, entitled "Project Library Ripoff," was distributed. Both oral and written instructions encouraged frank and honest answers, indicating that responses were privileged information, and that no penalty would occur.

The questionnaire contained several sections, including both rating and multiple-choice items. The first section pertained to background data, including such items as subject's sex, age, year in college, religious affiliation, etc. Items were also included covering academic experience, library familiarity and use, attitudes toward mutilation and toward use of the copy machine, circumstances of mutilation, penalties, and replacement. A record of most of these questions is included in the four tables in this article.

Two sections contained explicit rating items with responses obtained on a fivepoint numerical scale with scale endpoints labeled as either "completely true" and "completely false," or "com- pletely agree" and "completely disagree." These sections are also reproduced in the tables (with the two highest and two lowest rating categories each combined).

The last section of the questionnaire presented several library options for prevention (e.g., closed reserve, limited access, etc.) and asked subjects to check one of three alternatives with respect to tearing out articles. These items are shown in Table 4.

One critical item asked subjects to sign their name and record their phone number if they would be willing to be interviewed about the library. Four students who indicated they had ripped out articles signed their names. Three of these students were subsequently contacted for an interview. The students individually reported to a psychologist's office (the first author) from which a call was placed to a member of the library staff (the second author) for an anonymous telephone interview. These interviews were quite informative in "fleshing out" the picture of students' feelings and motives in defacing library materials. Detailed questions were asked on: (1) events preceding ripping outtheir assignment, class, intention, etc.; (2) circumstances-type of periodical, use of index, how, when, and where; (3) attitudes toward ripped-out volumes, periodicals versus books, difficulty in finding periodicals, hostility toward the library; (4) photocopy machinespoor copy, pictures, lack of money and time; (5) penalties and getting caught; and (6) replacement problems and concern for others.

\section{Results}

The results of the questionnaire survey are presented in the next sections. In the initial section basic characteristics of the subject sample are described. The second section shows several sets of results, classified so that comparisons 
may be made for students who indicated that they had ripped out journal articles (the "ripoffs") versus students who had not ripped out articles (the "non-ripoffs").

\section{Characteristics of the Sample}

There were 63 males (37.5 percent of the sample) and 105 females (62.5 percent) who participated in the study. Females were somewhat overrepresented for the total university population, but this result is typical for volunteer research studies. The class percentages were: freshmen, 43 percent; sophomores, 31 percent; juniors, 17 percent; seniors, 8 percent; and graduate students, 1 percent. The sample was young, with 35.7 percent listing their age as eighteen or under, 28.0 percent listing their age as nineteen, and 36.3 percent listing their age as twenty, and twenty-one or older. As expected, most students were single (93.4 percent), with 5.4 percent married and 1.2 percent divorced. The students came from a varied religious background: Catholic 38.1 percent, Protestant 36.9 percent, Jewish 7.7 percent, no religious faith 7.2 percent, and "other" 10.1 percent. Similarly, the sample was distributed across most of the colleges in the university and indicated a great variety of majors. The largest group of students (45.6 percent) was enrolled in Arts \& Science College, and the second largest group was from Fine \& Professional Arts (25.9 percent). Finally, most students (81.4 percent) indicated that they did (or had) worked full or part time to help pay for their college education.

The critical item on the questionnaire used to identify students who ripped out journal articles was "Have you ever in fact torn or cut out an article from a magazine in the KSU library? If yes, check the number of articles torn out in one year." There were 154 students (91.7 percent) who checked "none" while 14 students ( 8.3 percent) checked the alternatives "one," "two or three," "four or five," or "more than five." The admission rate of 8.3 percent is exceptionally close to the 8 percent rate obtained by the library staff at Bowling Green. Of the 14 students in this study who admitted tearing out articles, 5 were males ( 7.9 percent of all males) and 9 , females (8.6 percent of all females). Bowling Green found that 7 percent were repeaters while this study showed 3 percent repeaters. (However, interviews and comments indicated that many of those who checked "one article" were probably actually repeaters.)

\section{Comparisons: Ripoffs Versus Non-Ripoffs}

Comparisons are shown in Tables 1-4. In each case the 14 students admitting to being "ripoffs" were compared to the 154 students (non-ripoffs) who indicated they had not mutilated journals. Results are tabulated in percentage terms. Chi-square was used as a statistical test of significance for each comparison and the conventional probability level of .05 or smaller was the criterion for deciding whether a difference was significant. If a given comparison was significant (or nearly so), the probability is given in the last column of the tables. If the comparison was not significant, "n.s." appears in the last column. In computing the chi-squares between ripoffs and non-ripoffs, all the response categories in a question were used in making the test. However, for compactness in data presentation, categories are often combined. For example, students were asked to indicate their grade point with the alternatives 1.00 or less, 1.00 to $2.00,2.00$ to 3.00 , and 3.00 to 4.00 . In Table 1 these categories were combined as .00 to 3.00 and 3.00 to 4.00 . Other items were combined in a similar fashion to reduce the number of categories.

Results are presented in terms of the 
following categories: student perception on mutilation, general attitudes toward the library, attitudes toward use of the copy machine, and opinions on preventive measures.

Student perception on mutilation. These results are shown in Table 1. The top section indicates that students did not consider mutilation as a severe offense. The great majority were unconcerned about getting caught (ripoffs were totally unconcerned, 100 percent versus 68.8 percent for non-ripoffs); believed that it is easy to tear out an article ( 92 percent or higher); thought that mutilation is either not a crime or a minor misdemeanor; and stated that a fine paid to the library (ripoffs, 85.7 percent; non-ripoffs, 77 percent) should be the penalty. Clearly, for both ripoffs and non-ripoffs, journal mutilation was not high on a priority list of horrendous behavior.

Congruent with this observation 100 percent of the ripoffs and 63.4 percent of the non-ripoffs stated that they would do nothing if they saw someone else tearing out an article. However, better than 35 percent of the non-ripoffs said that they would take some action, resulting in the significant difference between the two groups. Only 43.4 percent of non-ripoffs and 21.4 percent of the ripoffs rated the act as "definitely wrong."

Student perceptions of replacement were grossly inaccurate. Over half (58.4 percent) of the ripoffs estimated three days to one week to replace an article and 46.1 percent of them judged the cost at $\$ 0.25$. These judgments may be a defensive maneuver to justify their actions. The non-ripoffs were more accurate, but over 55 percent estimated replacement cost as $\$ 1.00$ or less, about one-tenth of the actual cost. These data suggest that simple, factual education of the student body on the cost issue might drastically reduce mutilation rate.
This pattern of ignorance about the library is further indicated in the subsection of Table 1 on familiarity. A full 90 percent or better of all subjects had either "none" or "slight" technical familiarity with the library. Neither did they use the library very much. A full 25 percent of the ripoffs said they spend an average of "zero" hours per week in the library, and 57.2 percent of them "almost never" go to the library. The non-ripoffs attended somewhat more often; only 33 percent rated "almost never" and only 14.4 percent spend an average of "zero" hours per week. The differences between the two groups were not significant, however.

With regard to circumstances of use, 81 percent of non-ripoffs and 64.3 percent of ripoffs stated that they have never or only once in a while been inconvenienced by torn-out articles while 35.7 percent of ripoffs and only 19 percent of non-ripoffs have been "moderately" to "frequently" inconvenienced.

The item "Have you ever considered tearing out an article" was something of a check question. Of the non-ripoffs 32.5 percent had considered it, and of course logically all the ripoffs should have (actual rating percentage was $92.9)$. Students tended to perceive their fellow students as mutilators. Their estimates of the percent of students who mutilated were quite high; 92.9 percent of the ripoffs and 78.5 percent of the non-ripoffs judged the rate as 21 percent or higher.

This assessment of student perceptions yields an image of students as relatively unconcerned about mutilation; they assume it is relatively trivial and easily repaired, and in general they are unaware of the great costs and effort involved in this problem. Clearly a job of education is in order.

General attitudes toward the library. These results are presented in Table 2. Inspection of Table 2 indicates that stu- 
TABLE 1

Student Perceptions on MUtilation

\begin{tabular}{|c|c|c|c|c|}
\hline Items & Response Alternatives & $\begin{array}{l}\text { Perc } \\
\text { Ripoffs } \\
(\mathrm{N}=14)\end{array}$ & $\begin{array}{l}\text { ent of } \\
\text { Non-Ripoffs } \\
(\mathrm{N}=154)\end{array}$ & $\begin{array}{l}\text { Significance } \\
\text { of } \\
\text { Difference }\end{array}$ \\
\hline \multicolumn{5}{|l|}{ Being Caught and Penalty } \\
\hline $\begin{array}{l}\text { If you have actually torn out } \\
\text { an article or considered it, } \\
\text { were you concerned with } \\
\text { being caught? }\end{array}$ & $\begin{array}{l}\text { No to somewhat concerned } \\
\text { Moderately to very concerned }\end{array}$ & $\begin{array}{r}100.0 \\
0.0\end{array}$ & $\begin{array}{l}68.8 \\
31.2\end{array}$ & .05 \\
\hline $\begin{array}{l}\text { How easy do you think it } \\
\text { would be to tear out an } \\
\text { article? }\end{array}$ & $\begin{array}{l}\text { Very to moderately easy } \\
\text { Somewhat to very difficult }\end{array}$ & $\begin{array}{r}92.3 \\
7.7\end{array}$ & $\begin{array}{r}94.1 \\
5.9\end{array}$ & n.s. \\
\hline $\begin{array}{l}\text { What do you believe is the } \\
\text { penalty for ripping off } \\
\text { library materials? }\end{array}$ & $\begin{array}{l}\text { None } \\
\text { Misdemeanor and above }\end{array}$ & $\begin{array}{l}41.7 \\
58.3\end{array}$ & $\begin{array}{l}33.1 \\
66.9\end{array}$ & n.s. \\
\hline $\begin{array}{l}\text { What in your opinion should } \\
\text { be the penalty? }\end{array}$ & $\begin{array}{l}\text { None } \\
\text { Fine } \\
\text { More severe }\end{array}$ & $\begin{array}{r}14.3 \\
85.7 \\
0.0\end{array}$ & $\begin{array}{r}4.6 \\
77.0 \\
18.4\end{array}$ & n.s. \\
\hline \multicolumn{5}{|l|}{ Attitude Toward Ripping Off } \\
\hline $\begin{array}{l}\text { If you saw someone tearing } \\
\text { out, what would you do? }\end{array}$ & $\begin{array}{l}\text { Nothing } \\
\text { Ask to stop, or report it }\end{array}$ & $\begin{array}{r}100.0 \\
0.0\end{array}$ & $\begin{array}{l}63.4 \\
36.6\end{array}$ & .05 \\
\hline $\begin{array}{l}\text { Do you feel that tearing out } \\
\text { a magazine article is morally } \\
\text { wrong? }\end{array}$ & $\begin{array}{l}\text { No, not at all } \\
\text { Somewhat, very minor } \\
\text { Yes, definitely wrong }\end{array}$ & $\begin{array}{l}21.4 \\
57.2 \\
21.4\end{array}$ & $\begin{array}{l}10.0 \\
46.6 \\
43.4\end{array}$ & .03 \\
\hline \multicolumn{5}{|l|}{ Replacement } \\
\hline $\begin{array}{l}\text { What would be the time } \\
\text { period to replace a torn out } \\
\text { article? }\end{array}$ & $\begin{array}{l}\text { Three days to one week } \\
\text { One to three months } \\
\text { Six months }\end{array}$ & $\begin{array}{r}58.4 \\
41.6 \\
0.0\end{array}$ & $\begin{array}{l}26.8 \\
61.1 \\
12.1\end{array}$ & .002 \\
\hline $\begin{array}{l}\text { What would be the cost of } \\
\text { replacing a torn out article? }\end{array}$ & $\begin{array}{l}\$ 0.25 \\
\$ 1.00 \\
\$ 5.00 \text { to } \$ 10.00 \\
\$ 15.00\end{array}$ & $\begin{array}{r}46.1 \\
38.5 \\
15.4 \\
0.0\end{array}$ & $\begin{array}{r}8.7 \\
47.0 \\
40.9 \\
3.4\end{array}$ & .002 \\
\hline \multicolumn{5}{|l|}{ Academic Experience } \\
\hline Gradepoint & $\begin{array}{l}0.00 \text { to } 3.00 \\
3.00 \text { to } 4.00\end{array}$ & $\begin{array}{l}42.9 \\
57.1\end{array}$ & $\begin{array}{l}61.3 \\
38.7\end{array}$ & n.s. \\
\hline $\begin{array}{l}\text { Number of term papers done } \\
\text { so far? }\end{array}$ & $\begin{array}{l}\text { None to four } \\
\text { Five or more }\end{array}$ & $\begin{array}{l}57.1 \\
42.9\end{array}$ & $\begin{array}{l}77.3 \\
22.7\end{array}$ & n.s. \\
\hline \multicolumn{5}{|l|}{ Library Familiarity and Use } \\
\hline $\begin{array}{l}\text { Do you have technical } \\
\text { familiarity, such as working } \\
\text { in a library or taking library } \\
\text { science? }\end{array}$ & $\begin{array}{l}\text { Yes, a great deal } \\
\text { Slight } \\
\text { None }\end{array}$ & $\begin{array}{r}7.1 \\
42.9 \\
50.0\end{array}$ & $\begin{array}{r}4.6 \\
54.2 \\
41.2\end{array}$ & n.s. \\
\hline $\begin{array}{l}\text { How many times a week do } \\
\text { you go to the library? }\end{array}$ & $\begin{array}{l}\text { Almost never } \\
\text { Once a week to daily }\end{array}$ & $\begin{array}{l}57.2 \\
42.8\end{array}$ & $\begin{array}{l}33.0 \\
66.2\end{array}$ & n.s. \\
\hline $\begin{array}{l}\text { How many hours a week do } \\
\text { you spend in the library? }\end{array}$ & $\begin{array}{l}\text { Zero hours } \\
\text { One to sixteen hours }\end{array}$ & $\begin{array}{l}25.0 \\
75.0\end{array}$ & $\begin{array}{l}14.4 \\
85.6\end{array}$ & n.s. \\
\hline \multicolumn{5}{|l|}{ Circumstances } \\
\hline $\begin{array}{l}\text { Have you ever been } \\
\text { inconvenienced by a torn } \\
\text { out article? }\end{array}$ & $\begin{array}{l}\text { Never, to once in a while } \\
\text { Moderately to frequently }\end{array}$ & $\begin{array}{l}64.3 \\
35.7\end{array}$ & $\begin{array}{l}81.0 \\
19.0\end{array}$ & n.s. \\
\hline $\begin{array}{l}\text { Have you ever considered } \\
\text { tearing out an article? }\end{array}$ & $\begin{array}{l}\text { Occasionally to frequently } \\
\text { Never }\end{array}$ & $\begin{array}{r}92.9 \\
7.1\end{array}$ & $\begin{array}{l}32.5 \\
67.5\end{array}$ & .001 \\
\hline $\begin{array}{l}\text { What percentage of students } \\
\text { rip off an article? }\end{array}$ & $\begin{array}{l}0 \text { to } 20 \text { percent } \\
21 \text { percent and above }\end{array}$ & $\begin{array}{r}7.1 \\
92.9\end{array}$ & 21.5 & n.s. \\
\hline $\begin{array}{l}\text { Did you know that } \\
\text { periodicals can be checked } \\
\text { out overnight? }\end{array}$ & $\begin{array}{l}\text { Yes } \\
\text { No }\end{array}$ & $\begin{array}{l}42.9 \\
57.1\end{array}$ & $\begin{array}{l}51.3 \\
48.7\end{array}$ & n.s. \\
\hline
\end{tabular}


TABLE 2

Summary of "General Attitudes Toward the Library"

\begin{tabular}{|c|c|c|c|c|c|}
\hline Attitude Items & $\begin{array}{l}\text { Ripoffs vs. } \\
\text { Non-Ripoffs }\end{array}$ & $\begin{array}{l}\text { Res } \\
1+2 \\
\text { (False) }\end{array}$ & $\begin{array}{l}\text { nse Cat } \\
3\end{array}$ & $\begin{array}{l}\text { ries } \\
\quad \begin{array}{l}4+5 \\
\text { (True) }\end{array}\end{array}$ & $\begin{array}{l}\text { Significance } \\
\text { of } \\
\text { Difference }\end{array}$ \\
\hline $\begin{array}{l}\text { In general, I feel very positive toward } \\
\text { the library. }\end{array}$ & $\begin{array}{l}\text { RO } \\
\text { NRO }\end{array}$ & $\begin{array}{l}0.0 \\
7.1\end{array}$ & $\begin{array}{l}42.9 \\
14.3\end{array}$ & $\begin{array}{l}57.1 \\
78.6\end{array}$ & n.s. $(.08)$ \\
\hline $\begin{array}{l}\text { The library is a cold and anonymous } \\
\text { place. }\end{array}$ & $\begin{array}{l}\text { RO } \\
\text { NRO }\end{array}$ & $\begin{array}{l}57.2 \\
64.7\end{array}$ & $\begin{array}{r}7.1 \\
15.7\end{array}$ & $\begin{array}{l}35.7 \\
19.6\end{array}$ & n.s. \\
\hline $\begin{array}{l}\text { I find the library staff to be quite } \\
\text { friendly and helpful. }\end{array}$ & $\begin{array}{l}\text { RO } \\
\text { NRO }\end{array}$ & $\begin{array}{l}7.1 \\
9.2\end{array}$ & $\begin{array}{l}35.7 \\
32.0\end{array}$ & $\begin{array}{l}57.2 \\
58.8\end{array}$ & n.s. \\
\hline I always find what I need in the library. & $\begin{array}{l}\text { RO } \\
\text { NRO }\end{array}$ & $\begin{array}{l}50.0 \\
26.8\end{array}$ & $\begin{aligned} 7.1 \\
25.5\end{aligned}$ & $\begin{array}{l}42.9 \\
47.7\end{array}$ & n.s. \\
\hline $\begin{array}{l}\text { I would have to say that I feel rather } \\
\text { negative toward the library as an } \\
\text { institutional part of KSU. }\end{array}$ & $\begin{array}{l}\text { RO } \\
\text { NRO }\end{array}$ & $\begin{array}{l}78.5 \\
79.3\end{array}$ & $\begin{array}{l}14.3 \\
16.9\end{array}$ & $\begin{array}{l}7.2 \\
3.8\end{array}$ & n.s. \\
\hline $\begin{array}{l}\text { I have been treated unfairly by the } \\
\text { library at least once-such as being } \\
\text { charged for a book I did not check out. }\end{array}$ & $\begin{array}{l}\text { RO } \\
\text { NRO }\end{array}$ & $\begin{array}{l}78.5 \\
81.7\end{array}$ & $\begin{array}{r}0.0 \\
11.1\end{array}$ & $\begin{array}{r}21.5 \\
7.2\end{array}$ & .02 \\
\hline $\begin{array}{l}\text { The library discriminates against } \\
\text { undergraduates because it has more } \\
\text { lenient checkout policies for faculty } \\
\text { and graduate students than for } \\
\text { undergraduates. }\end{array}$ & $\begin{array}{l}\text { RO } \\
\text { NRO }\end{array}$ & $\begin{array}{l}30.8 \\
40.2\end{array}$ & $\begin{array}{l}53.8 \\
48.7\end{array}$ & $\begin{array}{l}15.4 \\
11.1\end{array}$ & n.s. \\
\hline
\end{tabular}

dent attitudes toward the library were generally quite positive. The majority of students felt positive toward the library, did not think it is a cold anonymous place, found the library staff helpful, etc. Ripoffs did not differ significantly from non-ripoffs on most of these items. However, it can be seen that on each item in this section ripoffs had less favorable attitudes toward the library. There was also a significant difference in that more of the ripoffs (21.5 percent) than non-ripoffs ( 7.2 percent) felt that they had been treated unfairly by the library on occasion.

Attitudes toward use of the copy machine. These results are shown in Table 3. The first item strongly discriminated ripoffs from non-ripoffs. Of the ripoffs 78.6 percent believed the copy machines were too expensive while only 38.4 percent of non-ripoffs agreed with this.

It is commonly thought that ripoffs do not realize the inconvenience they are causing others. The contrary was found here in that only 7.1 percent of ripoffs believed that "no harm is done since chances are that no one else will need that particular article." However, they still showed a significant difference from non-ripoffs on this item.

Other than these two items, however, the two groups did not differ from each other. Generally, response patterns show considerable distribution across the rating categories, and no well-defined negative attitude toward the copy machine is evidenced.

Opinions on preventive measures. These results are shown in Table 4. Only one measure showed a significant difference between groups. For the preventive option of closed reserve, 62 percent of non-ripoffs stated that they would not tear it out (instructions stated "Imagine you need a periodical badly in a few hours") under this contingency. However, only 35.7 percent of the ripoffs indicated that closed reserve would serve as a complete deterrent.

The data show some other interesting results. As might be expected, free copying would reduce the mutilation rate, according to the subjects' ratings. How- 
TABLE 3

Summary of "Using the Copy Machine"

\begin{tabular}{|c|c|c|c|c|c|}
\hline Attitude Items & $\begin{array}{l}\text { Ripoffs vs. } \\
\text { Non-Ripoffs }\end{array}$ & (Disagree) & nse Cat & $\begin{array}{l}\text { ries } \\
\quad 4+5 \\
\text { (Agree) }\end{array}$ & $\begin{array}{l}\text { Significance } \\
\text { of } \\
\text { Difference }\end{array}$ \\
\hline Copy machines are too expensive. & $\begin{array}{l}\text { RO } \\
\text { NRO }\end{array}$ & $\begin{array}{l}14.3 \\
51.9\end{array}$ & $\begin{array}{l}7.1 \\
9.7\end{array}$ & $\begin{array}{l}78.6 \\
38.4\end{array}$ & .04 \\
\hline The copy machines take too long to use. & $\begin{array}{l}\text { RO } \\
\text { NRO }\end{array}$ & $\begin{array}{l}71.5 \\
87.6\end{array}$ & $\begin{array}{r}14.3 \\
9.1\end{array}$ & $\begin{array}{r}14.2 \\
3.3\end{array}$ & n.s. \\
\hline $\begin{array}{l}\text { The copy machines are usually out } \\
\text { of order. }\end{array}$ & $\begin{array}{l}\text { RO } \\
\text { NRO }\end{array}$ & $\begin{array}{l}57.1 \\
59.5\end{array}$ & $\begin{array}{l}21.4 \\
30.1\end{array}$ & $\begin{array}{l}21.5 \\
10.4\end{array}$ & n.s. \\
\hline $\begin{array}{l}\text { It is just too easy to tear out the articles } \\
\text { since no attempt is made to protect them. }\end{array}$ & $\begin{array}{l}\text { RO } \\
\text { NRO }\end{array}$ & $\begin{array}{l}42.9 \\
40.2\end{array}$ & $\begin{array}{l}14.3 \\
25.3\end{array}$ & $\begin{array}{l}42.8 \\
34.5\end{array}$ & n.s. \\
\hline $\begin{array}{l}\text { Many other students tear out articles; so } \\
\text { why should I have to pay for them. }\end{array}$ & $\begin{array}{l}\text { RO } \\
\text { NRO }\end{array}$ & $\begin{array}{l}42.8 \\
63.6\end{array}$ & $\begin{array}{r}7.1 \\
14.3\end{array}$ & $\begin{array}{l}50.1 \\
22.1\end{array}$ & n.s. (.09) \\
\hline $\begin{array}{l}\text { Probably students who "tear out" rather } \\
\text { than copying on the machine are just } \\
\text { trying to get even with the "system." }\end{array}$ & $\begin{array}{l}\text { RO } \\
\text { NRO }\end{array}$ & $\begin{array}{l}42.8 \\
50.3\end{array}$ & $\begin{array}{l}14.3 \\
18.3\end{array}$ & $\begin{array}{l}42.9 \\
31.4\end{array}$ & n.s. \\
\hline The library can easily replace that article. & $\begin{array}{l}\text { RO } \\
\text { NRO }\end{array}$ & $\begin{array}{l}58.4 \\
77.3\end{array}$ & $\begin{array}{l}16.6 \\
12.3\end{array}$ & $\begin{array}{l}25.0 \\
10.4\end{array}$ & n.s. \\
\hline $\begin{array}{l}\text { No harm is done since chances are that } \\
\text { no one else will need that particular } \\
\text { article. }\end{array}$ & $\begin{array}{l}\text { RO } \\
\text { NRO }\end{array}$ & $\begin{array}{l}71.5 \\
94.1\end{array}$ & $\begin{array}{r}21.4 \\
1.9\end{array}$ & $\begin{array}{l}7.1 \\
4.0\end{array}$ & .002 \\
\hline
\end{tabular}

ever, better than 60 percent of both groups also indicated that a penalty warning sign would serve as a complete deterrent. Two-week checkout for periodicals was a popular deterrent as well. Opinions were mixed as to the effectiveness of a publicity campaign. If student opinion translates into action, the single best deterrent (and probably least expensive) would be posted signs stating the exact (maximum) legal penalty for the crime. Certainly it is an option libraries might wish to consider seriously.

Based on the data presented thus far, the ripoffs did not seem to differ much in characteristics and opinions from the non-ripoffs. The two groups did not differ significantly on any of the demographic characteristics discussed earlier. One might suggest that the two groups are indeed from the same "population" and whether one becomes a "ripoff" or not depends upon immediate situational circumstances.

\section{INTERVIEWS AND Discussion}

A number of findings and possibilities emerged from the three interviews with ripoffs and from the open-ended questionnaire items. Some of this material is discussed, and suggestions based on it are made.

One issue of importance is the prior intent of students who mutilate journals. All three interviewees claimed they had not intended to rip off the materials before going to the library. For the two males, this is probably the case since both described feeble and ineffective attempts to use the copier. The female, however, admitted to being a multiple ripper on the questionnaire, and said in the interview that she ripped out because she was "lazy" and "didn't care about her schoolwork or anything else; always took the easiest way."

The motivation and specific circumstances for mutilation are also of interest. All three interviewees said they were motivated by assignments. One also said he tore an article out of Billboard magazine for his personal use. Two ripoffs had approached the periodical collection through Readers' Guide ("the big green books"), and the third had a citation given him by a friend in College 
TABLE 4

Summary Results for Preventive Measures

\begin{tabular}{|c|c|c|c|c|c|}
\hline Preventive Options & $\begin{array}{l}\text { Ripoffs vs. } \\
\text { Non-Ripoffs }\end{array}$ & $\begin{array}{l}\text { Res } \\
\text { Would make } \\
\text { no difference. } \\
\text { I would still } \\
\text { tear it out if } \\
\text { I could. }\end{array}$ & $\begin{array}{l}\text { ponse Categor } \\
\text { Would dis- } \\
\text { courage me } \\
\text { somewhat. }\end{array}$ & $\begin{array}{l}\text { I would not } \\
\text { attempt to } \\
\text { tear it out. }\end{array}$ & $\begin{array}{c}\begin{array}{c}\text { Significance } \\
\text { of } \\
\text { Difference }\end{array}\end{array}$ \\
\hline \multicolumn{6}{|l|}{ A. Closed Reserve } \\
\hline $\begin{array}{l}\text { Periodicals kept on closed } \\
\text { reserve, have to sign for it. }\end{array}$ & $\begin{array}{l}\text { RO } \\
\text { NRO }\end{array}$ & $\begin{array}{r}28.6 \\
8.0\end{array}$ & $\begin{array}{l}35.7 \\
30.0\end{array}$ & $\begin{array}{l}35.7 \\
62.0\end{array}$ & .03 \\
\hline \multicolumn{6}{|l|}{ B. Limited Access } \\
\hline $\begin{array}{l}\text { Don't have to sign for article } \\
\text { but periodicals can't be } \\
\text { removed from area. } \\
\text { Librarian stationed in area. }\end{array}$ & $\begin{array}{l}\text { RO } \\
\text { NRO }\end{array}$ & $\begin{array}{l}23.1 \\
12.7\end{array}$ & $\begin{array}{l}46.2 \\
47.3\end{array}$ & $\begin{array}{l}30.8 \\
40.0\end{array}$ & n.s. \\
\hline $\begin{array}{l}\text { C. Sign warning of penalty. } \\
\$ 500 \text { fine or thirty days in jail. }\end{array}$ & $\begin{array}{l}\text { RO } \\
\text { NRO }\end{array}$ & $\begin{array}{r}7.1 \\
12.8\end{array}$ & $\begin{array}{l}28.6 \\
25.7\end{array}$ & $\begin{array}{l}64.3 \\
61.5\end{array}$ & n.s. \\
\hline $\begin{array}{l}\text { D. Signs indicating cost of } \\
\text { replacement and time to replace. }\end{array}$ & $\begin{array}{l}\text { RO } \\
\text { NRO }\end{array}$ & $\begin{array}{l}14.3 \\
29.5\end{array}$ & $\begin{array}{l}50.0 \\
46.3\end{array}$ & $\begin{array}{l}35.7 \\
24.2\end{array}$ & n.s. \\
\hline $\begin{array}{l}\text { E. Arrangements where periodicals } \\
\text { could be checked out for two } \\
\text { weeks like books. }\end{array}$ & $\begin{array}{l}\text { RO } \\
\text { NRO }\end{array}$ & $\begin{array}{l}14.3 \\
12.8\end{array}$ & $\begin{array}{l}14.3 \\
15.4\end{array}$ & $\begin{array}{l}71.4 \\
71.8\end{array}$ & n.s. \\
\hline $\begin{array}{l}\text { F. A publicity campaign showing } \\
\text { extent of problem and urging } \\
\text { concern for others. }\end{array}$ & $\begin{array}{l}\text { RO } \\
\text { NRO }\end{array}$ & $\begin{array}{l}21.4 \\
27.3\end{array}$ & $\begin{array}{l}57.1 \\
41.3\end{array}$ & $\begin{array}{l}21.4 \\
31.3\end{array}$ & n.s. \\
\hline G. Availability of free copying. & $\begin{array}{l}\text { RO } \\
\text { NRO }\end{array}$ & $\begin{array}{l}7.1 \\
4.0\end{array}$ & $\begin{array}{r}7.1 \\
12.1\end{array}$ & $\begin{array}{l}85.7 \\
83.9\end{array}$ & n.s. \\
\hline
\end{tabular}

English, indexed in Education Index. This finding indicates again the need to protect these particular groups of periodicals.

A most striking factor in regard to time emerged. Two of the three interviewees mentioned that they had done it "just before the library closed." Another of the fourteen ripoffs (not interviewed) mentioned this factor on the questionnaire. Other non-ripoffs mentioned on their questionnaire that "need as the library was closing" was a reason some might tear out articles. This result has possible implications for supervision of the periodical area prior to closing time.

The questions of where and how the mutilation was done are of interest. All three interviewees used study carrels for the act of mutilation. Neatly ripped pages do not necessarily mean the premeditated act of carrying a razor, but simply that some subjects may usually carry penknives with them. This fact has implications since a great deal of the ripping appears to be a tense, hurried, unpremeditated affair. Removal of some study carrels from the periodical area or at least close surveillance of them might be helpful.

The interviewees were asked about the effects on them when they found articles ripped out by others. The two males said they were made "extremely angry" and the female expressed herself as "upset." All three felt it was a factor in their tearing out. Other ripoffs also mentioned this factor on their questionnaires, as did several non-ripoffs. To some extent, then, a hostile-aggressive motivation may be a determining factor. Many non-ripoffs also said that they were tempted to mutilate out of a desire to get even with their fellow students and the "stupid" library. It is clear that ripped-out articles form a breeding ground for more ripped-out articles.

One finding emerged from the inter- 
views which had not been anticipated. The interviewees stated they would not tear out of "books" because they were much more expensive. Book mutilation appeared to be something of a taboo since they viewed books as precious objects (no doubt due to the high capital outlay at the beginning of each quarter). However periodicals were regarded as cheap. They expressed a tendency and preference to tear out of current periodicals. All three also stated that they would hesitate to tear out of a clean volume while one with ripped-out articles was already "ruined."

The fourteen ripoffs reported a total of seventeen instances of mutilation. Comments on the questionnaire indicated that in eight cases students probably attempted to use the copy machine and the following problems were encountered: no money, three; no change, two; library was closing, no time, one; copier won't do color photos, one; copier won't do fine print and tables, one. All of these problems could probably be prevented.

In the other nine cases the students probably did not attempt to use the machine. The reasons were as follows: tore out articles for personal pleasure and use, three; laziness, two; photocopy too expensive, two; hostility at ripped out articles and missing periodicals, two. These latter problems would probably be harder to prevent since they indicate an egocentric attitude and a general lack of concern for others.

One female ripoff expressed the attitude in her interview that "if you're going to tear out, you're going to tear out" and seemed to feel her problem was a character defect of "laziness." Another female ripoff expressed it as "laziness and orneriness." Surprisingly enough, however, most of the ripoffs appeared preventable.

Signs posted about overnight checkout might have prevented one ripoff. Anoth- er two might have been prevented by a sign showing where to get change and another three by a photocopy loan fund. Another might have been prevented by a better quality copier and possibly four others by a copier which would reproduce color photos. Two others might have been prevented by prompt replacement of ripped-out articles. It was the second author's impression that one of the ripoffs interviewed was extremely surprised in learning about replacement costs and that his attitude appeared to change so much that he might even have been willing to lead a crusade against future ripoffs.

This study also indicates some rather simple things libraries can do to reduce the rate of mutilation. The authors believe that a vigorous but inexpensive publicity campaign, particularly in regard to replacement costs (annually repeated) will considerably reduce mutilation. Basically decent motivation on the part of the vast majority of students must be assumed. But they are appallingly ignorant of the cost of replacement. Publicity in the sense of education about the library should help.

The world is full of warning signswhy not in the library as well? This factor should further reduce the incidence of mutilation. Of course signs can insult and anger also, so care must be taken. Probably, a simple sign stating the applicable section of the legal code and penalties is adequate. Some libraries have already taken steps in this matterfor example the University of Idaho, which imposes a fine of $\$ 125$ and/or expulsion. ${ }^{4}$

Other libraries should follow with orderly and fair procedures for enforcement, strongly supported by an educational campaign. Other measures hardly need stating, such as willingness to show students how to use the copy machine, courtesy in helping students and, most importantly, programs which will re- 
duce the hostility and alienation which some of the ripoffs feel toward the library. It is also important that rippedout material be replaced promptly and that unobtrusive surveillance be maintained in critical areas.

In conclusion, it is the opinion of the authors that there is no reason why li- braries should continue to suffer the problem of mutilation in silence. Many of us consider such mutilation an insult to the storehouse of civilization. This study appears to indicate that, though it is difficult, it should be possible to prevent a good deal of the mutilation which now takes place.

\section{REFERENCES}

1. Unpublished data provided by Angela Poulos, reference librarian, Bowling Green State University, Bowling Green, Ohio.

2. R. G. Martin, "Mutilation: A College and University Survey Concerning Microfilm Replacement for Mutilated Periodicals and Circulation of Microforms," Nebraska Library Association Quarterly 3:18-20 (Winter 1972).

3. Barbara Feret, 'Back to Student Rip-Offs' Point of Sale," Wilson Library Bulletin 47: 46 (Sept. 1972); Goldie Marshall, "Troubled by Page Slashers?" Library Journal 85: 23 (Nov. 15, 1960); William L. Emerson, "Theft and Mutilation," Library Journal 85:
208 (Jan. 15, 1960); “'Jack the Ripper' Is Apprehended in So. Dakota," Library Journal 97:2680 (Sept. 1, 1972); Robert Lightfoot, "Project Mutilation: An Attempt at a Solution to a Growing Problem," Illinois Libraries 52:946 (Nov. 1970); Ronald Hoppe and Edward Simmel, "Booktearing and the Bystander in the University Library," $\mathrm{Col}$ lege \& Research Libraries 30:247-51 (May 1969); Lee Zimmerman, "Pilfering and Mutilating Library Books," Library Journal 86: 3437-40 (Oct. 15, 1961).

4. "Again-Book Thefts and Mutilation," Bookmark (Idaho) 13:1 (Sept. 1960). 